\title{
FORMATION OF ANTIBACTERIAL EFFECT ON CERAMIC TILE SURFACES
}

\author{
Selçuk ÖZCAN ${ }^{1,}$, , Nurcan ÇALIŞ AÇIKBAŞ ${ }^{2}$, Gökhan AÇIKBAŞ ${ }^{3}$ \\ ${ }^{1}$ Department of Chemical and Process Engineering, Bilecik Şeyh Edebali University, Bilecik, Turkey \\ ${ }^{2}$ Department of Metallurgical and Materials Engineering, Bilecik Şeyh Edebali University, Bilecik, Turkey \\ ${ }^{3}$ Vocational School, Metallurgy Program, Bilecik Şeyh Edebali University, Bilecik, Turkey
}

\begin{abstract}
Biocidal antimicrobial molecular barrier (BAMB) solutions are known to provide antimicrobial effect on the surfaces in industrial applications. However, there has been a lack of scientific reports about the subject in the literature. In this study, in order to impart an antimicrobial surface property on ceramic surfaces, a BAMB solution was applied on gloss fired ceramic wall tile substrates and the surface antimicrobial activity results were compared with that of plain wall tiles (without BAMB application). The ceramic surfaces were cleaned, and stove dried at $120^{\circ} \mathrm{C}$ prior to spray coating with a BAMB solution. The coated substrates were dried in the ambient. The intactness of the coatings was checked with the bromophenol blue test. The microstructural and molecular characterization of the BAMB coated surfaces were carried out with SEM imaging and surface FTIR, respectively. The antimicrobial activity tests of the surfaces were conducted according to ASTM E2180-07 (Standard Test Method for Determining the Activity of Incorporated Antimicrobial Agent in Polymeric or Hydrophobic Materials). The microorganisms used were Staphylococcus aureus (ATCC 6538) and Pseudomonas aeruginosa (ATCC 15442) bacteria. The BAMB coated surfaces showed less flocculent bacterial growth in comparison to uncoated ceramic surfaces leading to the conclusion that the BAMB improved the antimicrobial property.
\end{abstract}

Key words: Biocidal antimicrobial molecular barrier (BAMB), Surface coating, Antimicrobial effect, Ceramics, Antimicrobial characterization

\section{INTRODUCTION}

The death rates due to skin contact with the potentially pathogenic microorganisms (bacteria, fungus, viruses) in clinical, industrial, and household environments are considerable. The hospital infections and various dermatomes are among the potential health risks [1]. Accordingly, the demand for antimicrobial floor and wall coating materials in clinical, industrial and domestic spaces, especially on wettable surfaces as well as antimicrobial textiles is expected to increase.

An antimicrobial surface contains agents that physically, chemically or biologically inhibiting or reducing the proliferation of microorganisms that has migrated on [2]. The antimicrobial surfaces are mostly formed by functional coatings. A surface with a coating that incorporates chemical agents toxic to microorganisms, or permanently adsorbed or absorbed polymeric substances or polypeptide chains biologically or simply physically interfering with microorganisms may provide surface antimicrobial effect. Silver or copper absorbed in zeolite or $\mathrm{TiO}_{2}$ carriers, biguanide, chitosan, bis-chlorinated phenols (Triclosan), organo-tin compounds (TBT), heavy metal ( $\mathrm{Pb}, \mathrm{Hg}, \mathrm{As}$ )-organo complexes, water soluble quaternary compounds distributed in a surface coating or impregnated in a body constitute examples of migrating antimicrobials. The action mechanism of migrating antimicrobials is the leaching or diffusion of the active component in a wet or humid environment to be taken up by microorganisms. Their disadvantage is the gradual loss of the effectiveness, and the generation of resistant microorganism strains [3-9]. The non-migrating antimicrobials are fixed on a surface and cannot be consumed by microorganisms, hence, do not have the disadvantages related to the migration of the active component.

*Corresponding Author: selcuk.ozcan@bilecik.edu.tr 
Organo-functional silanes, $\mathrm{N}$-halamines, radiation polymerization grafted organic monomer components constitute examples of non-migrating antimicrobials [10].

Hydrophobic surfaces, in general, are known to have antimicrobial effect by restricting the adherence of microorganisms on the surface. The hydrophobic or super-hydrophobic character of a surface can be achieved chemically and/or morphologically. However, ceramic coating products are produced by high temperature processes with the inevitable outcome of a hydrophilic surface. In the literature, it was shown that hydrophobic character could be imparted to a ceramic material surface by polymeric coatings of specific morphology. However, the adhesion strength of the polymer layer was well below that was required of a usable product $[5,6]$.

The idea and applications of treating or preventing skin infections with antimicrobial effect imparted clothing is developing. Antimicrobial silk clothing was reported to be successfully utilized in the treatment of atopic dermatitis. The severity of eczema was correlated with the quantity of Staphylococcus aureus colonizing the skin of the patients [11,12]. It was shown that silane quaternary ammonium compounds chemisorbed on textile substrates provided for the broad spectrum control of microorganisms and were well suited in a range of applications in the medical industry. The nonmigrating biocidal agent permanently fixed on woven and nonwoven medical textiles by covalent bonding such as fenestrations of surgical drapes, mayo stand covers, uniforms, sponges, and linens were among the successfully utilized products [13]. It was demonstrated that the antibacterial, antifungal, antiviral, anti-algal, and anti-protozoal activity of this type of textile surface bonded agent against a broad spectrum of microorganisms continued even after repeated washings [14].

In this study, ceramic tiles with hydrophilic surfaces was spray coated with a commercial BAMB solution in order to assess the antimicrobial effectiveness of the surfaces in the absence of any intermediate hydrophobic polymer layer. The BAMB molecule used is 3-(trimethoxysilyl) propyl dimethyl octadecyl ammonium chloride, and when covalently linked to a surface the compound is known to show non-migrating antimicrobial effect [10]. The silan (trimethoxysilyl) base of the molecule is capable of covalently bonding to many type surfaces including glass, ceramics, wood, polymers and metals, hence with an exceedingly high adhesion strength. The positively charged middle section of the molecule is effective in the migration of microorganisms onto the chain structured tip section of the molecule. The spike field obtained by such a barrier coating on the surface causes the membrane of the microorganism to be punctured with catastrophic collapse avoiding microorganism colonies or floccules to form (Figure 1). The coating can easily be tailored to a homogeneous, uniform molecular monolayer which will function as an antimicrobial barrier with only physical action (Figure 2).

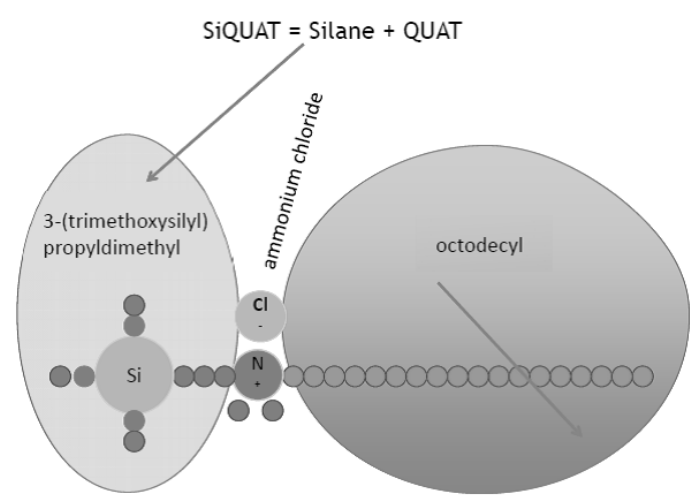

Figure 1. Schematic structure of a representative barrier molecule [15] 


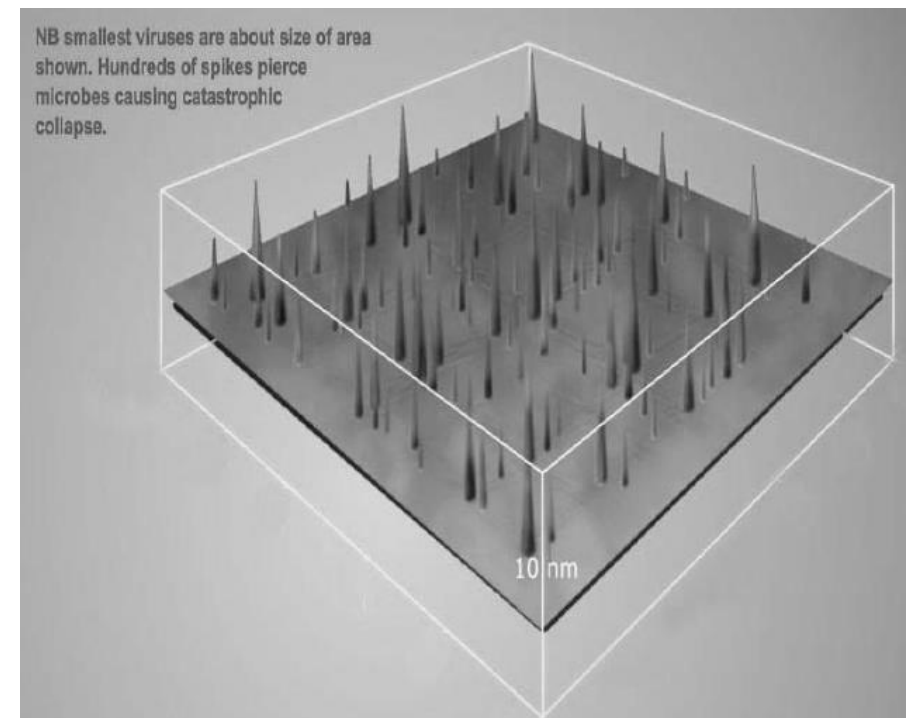

Figure 2. Schematic SEM image of an antimicrobial molecular barrier obtained by coating with a BAMB solution [15]

\section{MATERIALS AND METHODS}

The ceramic glazed wall tiles that were used as substrates for the BAMB application were obtained from Bien Ceramic Tiles Plant located in Bilecik, Turkey. The tile sizes were $5 \times 5 \mathrm{~cm}$.

The biocidal antimicrobial molecular barrier (BAMB) solution was obtained from Gereme - Curtisium Bamb A.Ş., Torbali, Izmir, in a $1 \mathrm{~L}$ package. It comprises $0.5 \%(\mathrm{w} / \mathrm{v}) 3$-(trimethoxysilyl)-propyl dimethyl octadecyl ammonium chloride aqueous solution with a density of $1.0 \mathrm{~g} / \mathrm{L}$. The molecular formula of 3-(trimethoxysilyl)-propyl dimethyl octadecyl ammonium chloride is $\left[\left(\mathrm{CH}_{3} \mathrm{O}\right)_{3} \mathrm{Si}\left(\mathrm{CH}_{2}\right)_{3} \mathrm{~N}\left(\mathrm{CH}_{3}\right)_{2}\left(\mathrm{CH}_{2}\right)_{17} \mathrm{CH}_{3}\right] \mathrm{Cl}$ with the molecular weight 496.28 and the CAS number 27668-52-6. The chemical structure is given in Figure 3.<smiles>[10BH2][N+](C)(C)CCC[Si](C)(OC)OC</smiles>

Figure 3. Chemical structure of 3-(trimethoxysilyl)-propyl dimethyl octadecyl ammonium chloride

The glazed ceramic wall tile surfaces were cleaned successively with a detergent solution and $70 \%$ ethanol solution, followed by rinsing with deionized water and stove drying at $120^{\circ} \mathrm{C}$. The substrate surfaces were coated with the biosidal antimicrobial molecular barrier solution by atomized spraying. The solution was atomized by high pressure air forcing the liquid through an adjustable aperture nozzle, and the size of the droplets was adjusted to obtain a continuous liquid film on the ceramic tile substrate. Approximately $1 \mathrm{~mL}$ of solution was applied per $\mathrm{cm}^{2}$ of the substrate. The bonding mechanism of the molecules to a silicon containing surface is through the sequential hydrolysis and condensation reactions of the trimethoxysilane base of the molecule with the surface metal atoms as well as polymerizing with the silicon atoms in other barrier molecules. 
The intactness of the coating was checked with the bromophenol blue test method (BTM01-07242009). $0.01 \%(\mathrm{w} / \mathrm{v})$ bromophenol blue solution was poured onto the substrate which was placed in a $150 \mathrm{~mL}$ glass container. The substrates were held submerged in the solution for 15 minutes at ambient temperature and then were rinsed with deionized water. Bromophenol blue reacts with the quaternary ammonium of the barrier molecule fixing it against water rinsing. The shade of the blue color on the surface was taken as an indicator of the monolayer packing density of the molecules.

In order to determine the surface covalent bonding of the barrier molecules a Perkin Elmer Spectrum 100 model Fourier transform infrared spectrometer (FTIR) was used.

A Zeiss, Supra 40 VP model scanning electron microscope (SEM) was used for surface microstructural analysis. The coated and uncoated surfaces were examined with secondary electron detector. The substrate surfaces were sputter coated with platinum to avoid charging during scan.

The antimicrobial tests were carried according to ASTM E2180-07 (Standard test method for Determining the Activity of Incorporated Antimicrobial Agent in Polymeric or Hydrophobic Materials) with the bacteria Staphylococcus aureus ATCC 6538 and Pseudomonas aeruginosa ATCC 15442 at Egemikal Lab, Ege University, Izmir.

For the purpose, reference cultures were developed in tryptic soy broth medium at $37 \pm 1^{\circ} \mathrm{C}$ for 18 hours. Those cultures were transferred at a density of $106 \mathrm{cfu} / \mathrm{mL}$ into a gelatinous (semi-solid) agar cooled down to $45^{\circ} \mathrm{C}$ (cfu/mL: colony forming unit per $\mathrm{mL}$ ). $500 \mu \mathrm{L}$ of the prepared culture suspension was spread on the priorly sterilized antimicrobial barrier coated and uncoated ceramic substrates. Subsequent to inoculation the substrates were incubated at $37 \pm 1^{\circ} \mathrm{C}$ for 24 hours. Following the incubation each substrate was placed in a neutralizing medium, and any bacteria on the substrate surface were transferred into the solution by vortexing. The solutions were diluted in the ratio1/10, and $1 \mathrm{~mL}$ of the diluted solution was mixed with $15 \mathrm{~mL}$ of tryptic soy agar in petri dishes. Following the incubation at $37 \pm 1^{\circ} \mathrm{C}$ for 48 hours the colonies formed were counted.

\section{RESULTS AND DISCUSSION}

The purpose of this study is to evaluate any antibacterial property enhancement that can be achieved by coating glazed ceramic wall tile substrates with a biocidal antimicrobial molecular barrier. The molecular barrier comprises of 3-(trimethoxysilyl)-propyl dimethyl octadecyl ammonium chloride molecules polymerized with each other through $\mathrm{Si}$-O-Si bonds, and covalently bonded on the substrate surface by Si-O-M bonds ( $\mathrm{M}$ represents metal, metalloid or carbon atoms on the surface) forming a surface network of molecular spikes (Figure 4). The spikes are supposed to provide the antibacterial effect causing catastrophic collapse of the microorganisms by physically puncturing their membranes, or interfering with their protective layers.

In order to provide evidence for the formation of a surface molecular barrier network the ceramic substrates with or without BAMB application were compared according to their FTIR spectra as shown in Figure 5. The major differences of the spectrum of the molecular barrier solution applied substrate, in comparison to the plain glazed wall tile substrate, were the existence of the very broad prominent shoulder between $660-800 \mathrm{~cm}^{-1}$, and the very broad peak between $800-1220 \mathrm{~cm}^{-1}$ reaching its maximum at $865 \mathrm{~cm}^{-1}$. Si-C stretch in organosilicon compounds is given between $720-860 \mathrm{~cm}^{-1}, \mathrm{Si}_{-} \mathrm{CH}_{3}$ rocking in silanes are reported between $810-850 \mathrm{~cm}^{-1}$, and $\mathrm{Si}-\mathrm{O}-\mathrm{Si}$ antisymmetric stretch in siloxanes occurs between $1000-1100 \mathrm{~cm}^{-1}$ [20]. 


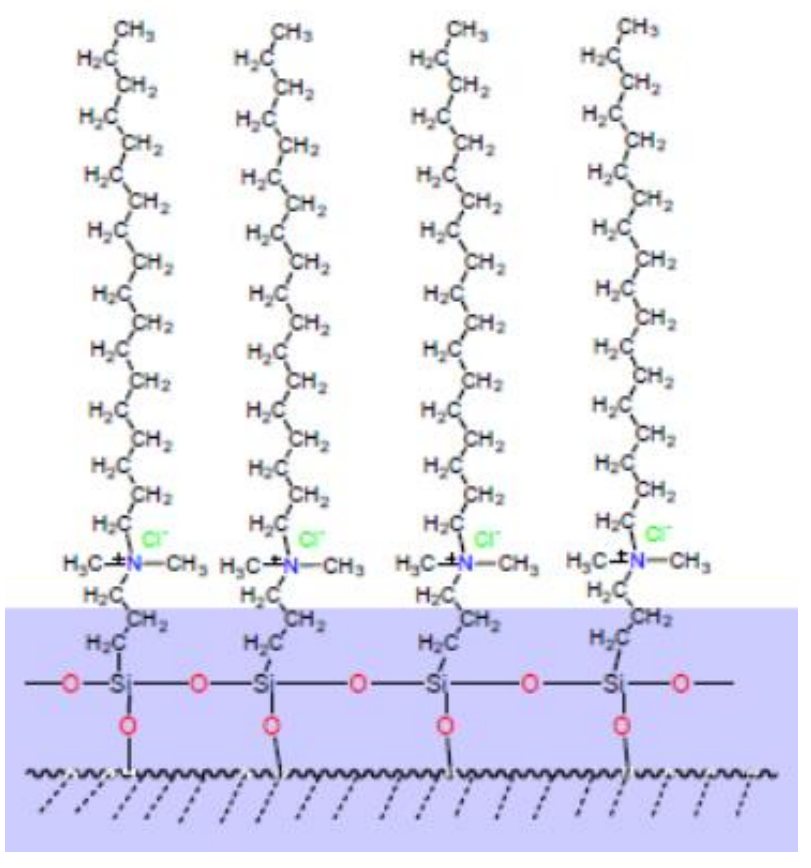

Figure 4. Molecular barrier network molecules covalently bonded on substrate surface [15]

Especially, the broad peak centered around $865 \mathrm{~cm}^{-1}$ was a clear indication of the existence of the Si-C bond structures on the surface. The shoulder at $1120 \mathrm{~cm}^{-1}$ within the broad peak could be related to Si$\mathrm{O}-\mathrm{Si}$ bonds providing further evidence of the surface polymeric network. A possible bond structure between the barrier molecule and the glazed ceramic surface was Si-O-Zn with the absorbance within the band $1153-1161 \mathrm{~cm}^{-1}$ matching with the $1150-1160 \mathrm{~cm}^{-1}$ absorbance bands within the broad peak [17]. Nevertheless, $\mathrm{SiO}_{2}$ absorbance occurred between 800 and $1260 \mathrm{~cm}^{-1}$ band superimposing the rest of the spectrum $[18,19]$.

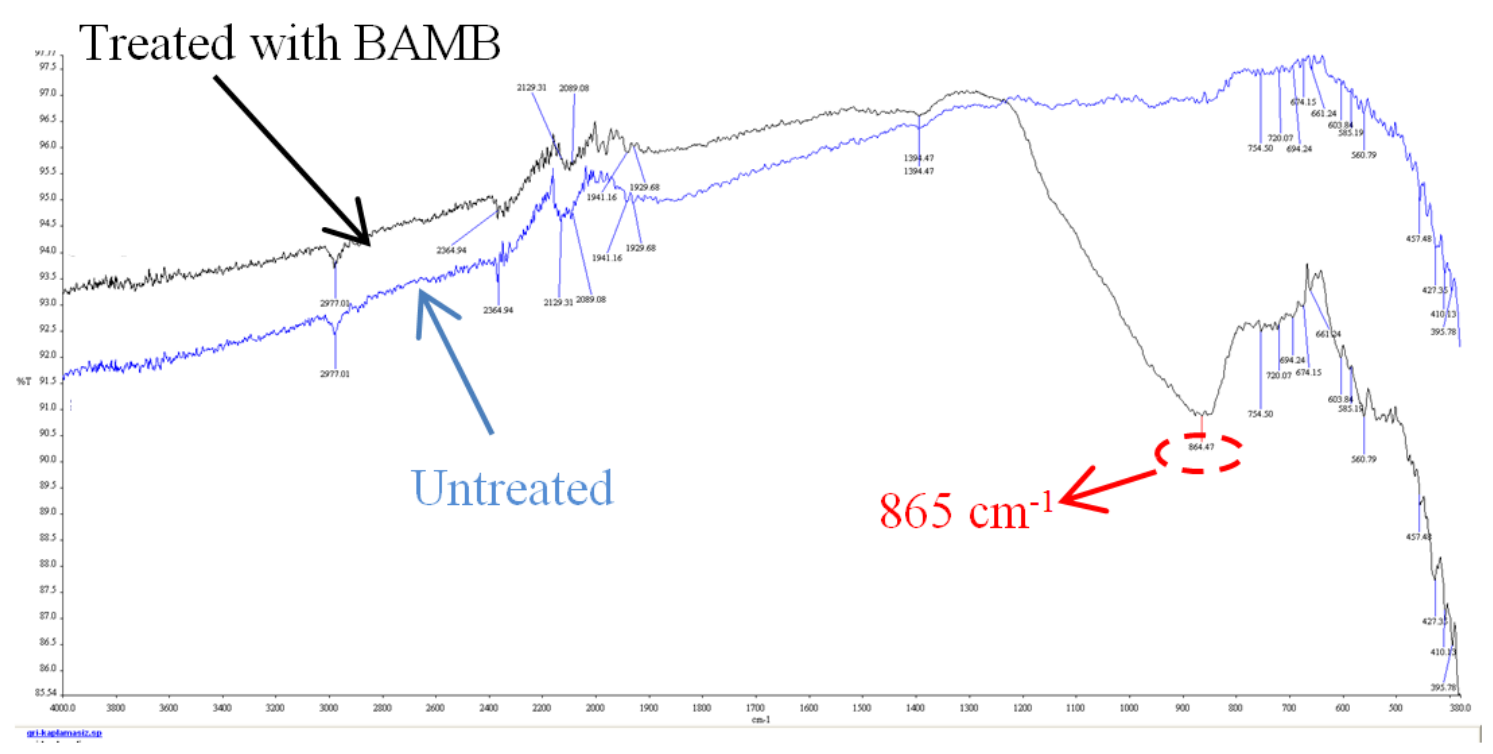

Figure 5. FTIR spectrum comparison of the surfaces with or without treatment with BAMB solution 
The secondary electron detector SEM pictures of the ceramic substrates with or without BAMB treatment are shown in Figure $6 \mathrm{a}$ and $6 \mathrm{~b}$. Both of the surfaces appeared to be of very similar microstructure with apparently similar roughnesses. This result was to be expected since the BAMB coating most probably formed a molecular network layer which could not be possibly detected with SEM. Therefore, the possibility of the formation of a thick film layer with BAMB application was eliminated.

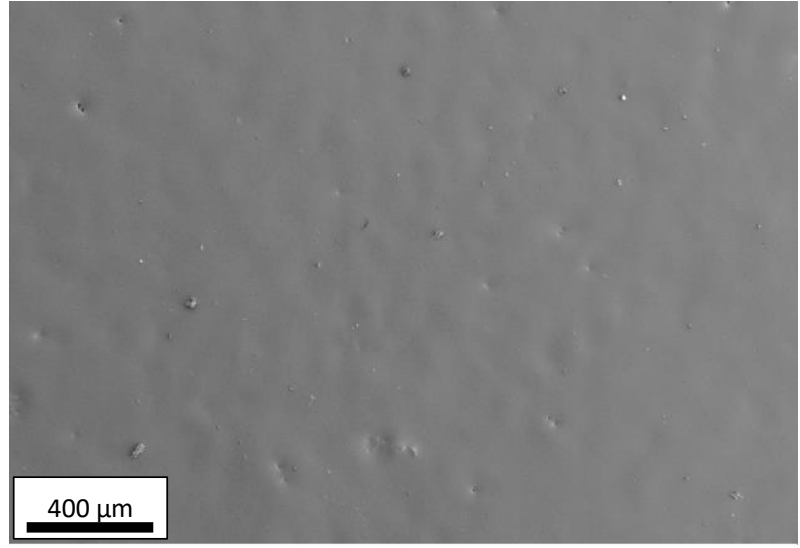

(a)

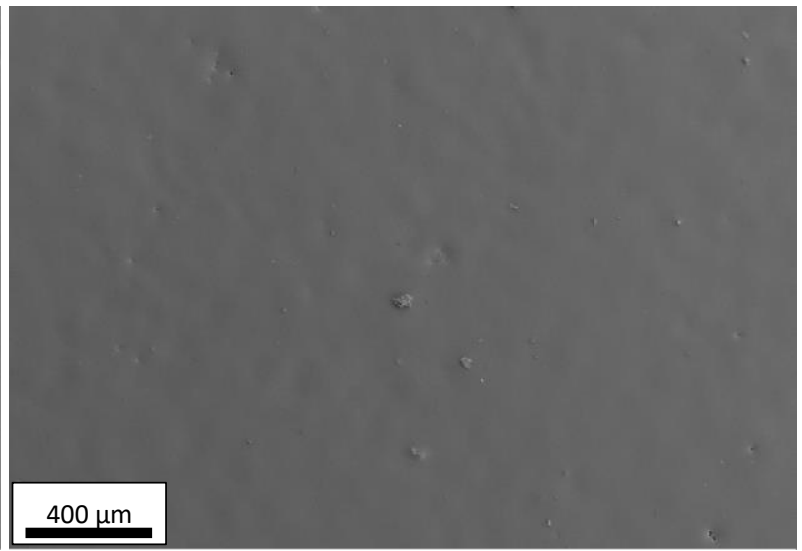

(b)

Figure 6. SEM picture of (a) plain ceramic surface and (b) BAMB treated ceramic surface

The bromophenol blue test result showed a uniform and homogeneous layer for the BAMB treated substrates further supporting a molecular barrier layer. There was no retaining blue color for the untreated substrates after rinsing with water as expected.

The surface covalent bonding of the 3-(trimethoxysilyl)-propyl dimethyl octadecyl ammonium chloride molecules on the substrate surface, as well as their polymerization by bonding with each other to form a surface network was due to the sequential hydrolysis and condensation reactions of the trimethoxysilyl $\left(-\mathrm{Si}-\mathrm{O}-\mathrm{CH}_{3}-\right)$ groups. After the hydrolysis one or more of the probable aquo $\left(-\mathrm{Si}-\mathrm{OH}_{2}\right)$, hydroxo $(-\mathrm{Si}-$ $\mathrm{OH})$, and/or oxo $(\mathrm{Si}=\mathrm{O})$ ligand groups were formed. Condensation occured through olation (-Si-OH-Si) and oxolation (-Si-O-Si-) reactions. Condensation via alcoxolation was also probable [20]. The $80 \%$ of the three dimensional silicate polymerization was reported to be with the preformed $\operatorname{dimer}\left(\mathrm{Q}_{2}{ }^{1}\right)$, cyclic trimer $\left(\mathrm{Q}_{3}{ }^{2}\right)$, linear trimer $\left(\mathrm{Q}_{2}{ }^{1} \mathrm{Q}^{2}\right)$, substituted cyclic trimer $\left(\mathrm{Q}^{1} \mathrm{Q}^{3} \mathrm{Q}_{2}{ }^{2}\right)$, cyclic tetramer $\left(\mathrm{Q}_{4}{ }^{2}\right)$, and prismatic hexamer $\left(\mathrm{Q}_{6}{ }^{3}\right)$ structures [20]. Thus the surface molecular network may or may not be visualized as a monolayer structure.

The antimicrobial test results are given in Table 1 and 2. Tests with both of the bacteria Staphylococcus aureus ATCC 6538, and Pseudomonas aeruginosa ATCC 15442 showed a drastic decrease in the number of bacterial colonies forming on the BAMB coated surfaces indicating a definite induced antibacterial property.

Table 1.Antibacterial activity with Staphylococcus aureus ATCC 6538 (24 hour incubation at $37 \pm 1^{\circ} \mathrm{C}$ )

\begin{tabular}{|c|c|c|c|}
\hline Test & $\begin{array}{c}\text { Untreated substrate } \\
\text { bacterial activity }(\mathbf{c f u} / \mathbf{m L})\end{array}$ & $\begin{array}{c}\text { BAMB treated substrate } \\
\text { bacterial activity } \\
(\mathbf{c f u} / \mathbf{m L})\end{array}$ & $\begin{array}{c}\text { Percent difference in } \\
\text { bacterial activity } \\
\boldsymbol{\%}\end{array}$ \\
\hline $\begin{array}{c}\text { ASTM } \\
\text { E2180-07 }\end{array}$ & 210,000 & 720 & 99,66 \\
\hline
\end{tabular}


Özcan et al. / Anadolu Univ. J. of Sci. and Technology A-Appl. Sci. and Eng. 18 (1)-2017

Table 2. Antibacterial activity with Pseudomonas aeruginosa ATCC 15442 (24 hour incubation at $\left.37 \pm 1^{\circ} \mathrm{C}\right)$

\begin{tabular}{|c|c|c|c|}
\hline Test & $\begin{array}{c}\text { Untreated substrate } \\
\text { bacterial activity }(\mathbf{c f u} / \mathbf{m L})\end{array}$ & $\begin{array}{c}\text { BAMB treated substrate } \\
\text { bacterial activity } \\
\text { (cfu/mL) }\end{array}$ & $\begin{array}{c}\text { Percent difference in } \\
\text { bacterial activity } \\
\text { \% }\end{array}$ \\
\hline ASTM & 560,000 & 25,000 & 95,54 \\
\hline
\end{tabular}

Figure 7 and 8 show the bacterial colonies in petri dishes of the diluted, proliferated bacterial solutions mixed with the agar after 48 hour incubation at $37 \pm 1^{\circ} \mathrm{C}$.
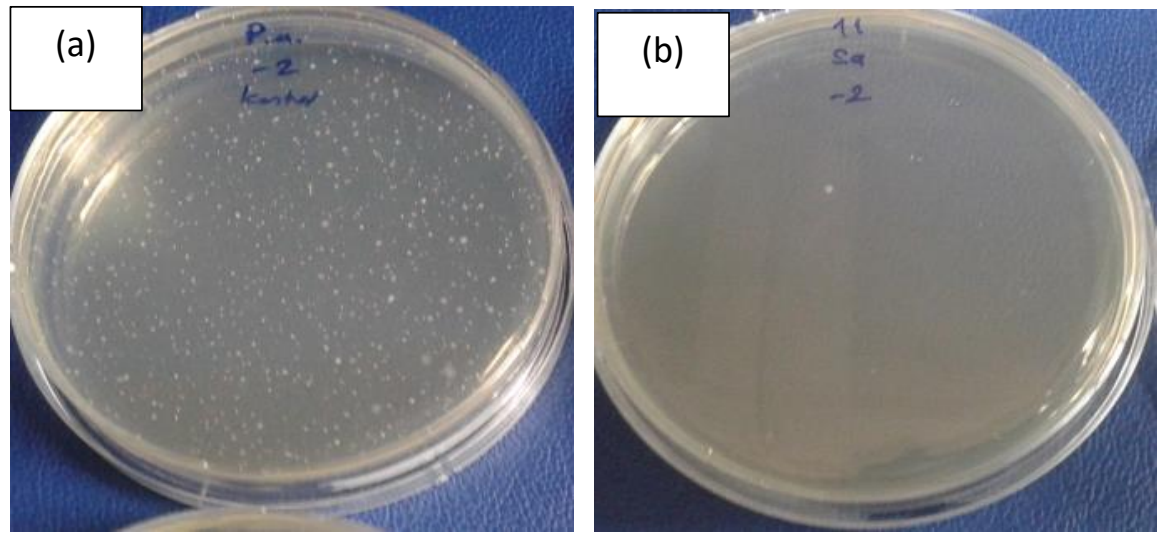

Figure 7. Staphylococcus aureus (ATCC 6538) colonies formed. (a) From the untreated ceramic substrate, (b) from the BAMB treated ceramic substrate.
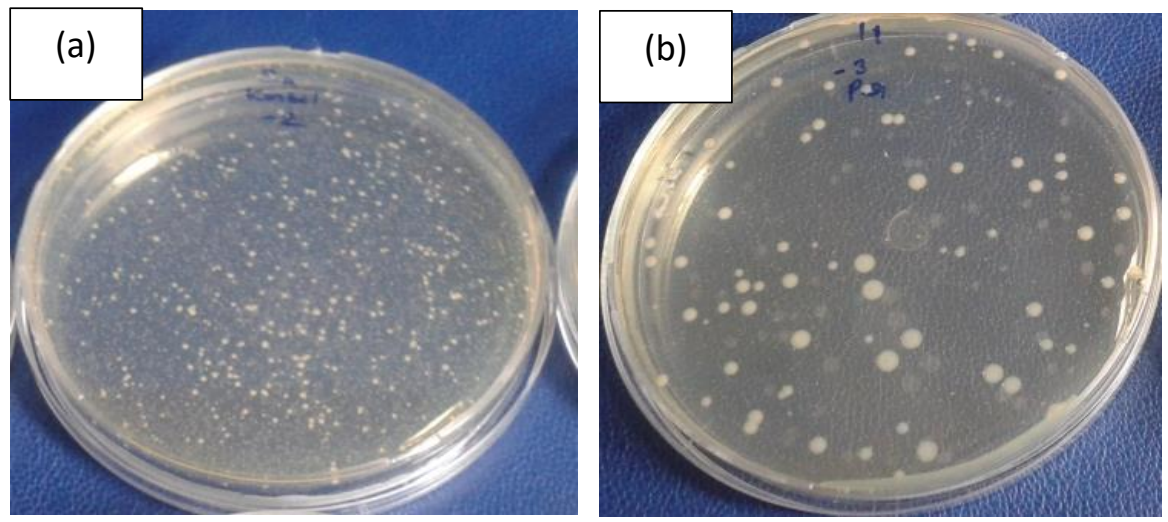

Figure 8. Pseudomonas aeruginosa (ATCC 15442) colonies formed. (a) From the untreated ceramic substrate, (b) from the BAMB treated ceramic substrate.

\section{CONCLUSIONS}

It is known that the medical textile products coated with silane quaternary ammonium compounds showed antimicrobial effect. However, for other surfaces coated with non-migrating biocidal agents, there is a lack of scientific evidence of covalent bonding on the surface, and antimicrobial efficacy. In the study, glazed ceramic wall tile substrates were treated with biocidal antimicrobial molecular barrier solution. The treated samples were shown to be coated with a covalently bonded molecular barrier 
Özcan et al. / Anadolu Univ. J. of Sci. and Technology A-Appl. Sci. and Eng. 18 (1)-2017

network by FTIR spectroscopy, secondary electron SEM, and bromophenol blue staining test. The covalent bonding of the barrier molecules to the glazed ceramic surface was formed through -Si-O-Mstructures as a result of hydrolysis and condensation reactions of the trimethoxy silyl groups. The results also indicated a molecular network on the surface polymerized with -Si-OH-Si- (ol) or -Si-O-Si- (oxo) bridges. The hydrophilic ceramic glazed ceramic surfaces when coated with the molecular barrier layer showed a decisively enhanced antibacterial property as evidenced by antimicrobial tests, reducing the microbial activity on the surface over $95 \%$. The study constitutes an example of permanent nonmigrating antibacterial coating on glazed ceramic wall tile surfaces.

\section{Acknowledgement}

The study was financially supported by Bilecik Şeyh Edebali University Scientific Research Fund (Project No: 2012-01-BİL.03-03). The support is gratefully acknowledged. The contributions of Bien Ceramic Tiles Plant A. S., and Egemikal Laboratories are gratefully acknowledged.

\section{REFERENCES}

[1] Onaizi SA, Leong SSJ. Tethering Antimicrobial Peptides. Biotechnology. Advances 2011; 29: 67-74.

[2] Anderson DM, chief lexicographer, Dorland's Illustrated Medical Dictionary, 32nd ed., Philadelphia, PA, Elsevier Saunders, 2010. pp.11-17.

[3] Battice D, Hale H. Antimicrobially Effective Organic Foams and Methods for their Preparation; U.S. Pat. 4631297, 1986.

[4] Higgs B, White W. Solid Antimicrobial. U.S. Pat. 5359104, 1994.

[5] Açıkbaş G, Kara F, Suvacı E. Sır Yüzeyinde Uçucu Organik İlavelerle Morfoloji Eldesi. Afyon Kocatepe Üniversitesi Fen Bilimleri Dergisi 2008; 280-288.

[6] Açıkbaş G, Seramik yüzeylerinde mikromorfoloji oluşturulması. Yüksek Lisans Tezi, Anadolu Üniversitesi, Eskişehir, Türkiye, 2007.

[7] Gürbüz M. Solaş A, Küçük A, Göktaş A, Doğan A. Nanoteknoloji ile Çevredostu Fotokatalitik ve Antimikrobiyal Seramik Malzemelerin Üretilmesi. Afyon Kocatepe Üniversitesi Fen Bilimleri Dergisi $2008 ; 217-221$.

[8] Doğan A, Pekşen C. Metal İyon Katkılı Antimikrobiyal Malzemelerin Hastane İnfeksiyonlarını Önlemede Katkıları ve Uygulamaları. 4. Ulusal Sterilizasyon Dezenfeksiyon Kongresi; 20-24 Nisan 2005; Samsun, Türkiye. 59-68.

[9] Üreyen ME, Çavdar A, Koparal AS, Doğan A. Yeni geliştirilen gümüş katkılı antimikrobiyal tekstil kimyasalı ve bu kimyasal ile işlem görmüş kumaşların antibakteriyel performansları. The Journal of Textiles and Engineers 2015; 69: 25-31.

[10] Isquith AJ, Abbott EA, Walters PA. Surface-Bonded Antimicrobial Activity of an Organosilicon Quaternary Ammonium Chloride. Applied Microbiology 1972; 24(6): 859-863.

[11] Senti G, Steinmann LS, Fischer B, Kurmann R, Storni T, Johansen P, Schmid-Grendelmeier P, Wuthrich B, Kundig TM. Antimicrobial Silk Clothing in the Treatment of Atopic Dermatitis Proves Comparable to Topical Corticosteroid Treatment. Pharmacology and Treatment 2006; 213(3): 228-233. 
Özcan et al. / Anadolu Univ. J. of Sci. and Technology A-Appl. Sci. and Eng. 18 (1) - 2017

[12] Ricci G, Patrizi A, Bendandi B, Menna G, Varotti E, Masi M. Clinical effectiveness of a silk fabric in the treatment of atopic dermatitis. British Journal of Dermatology 2004; 150: 127-131.

[13] White WC, Monticwello RA. Antimicrobial Performance of Medical Textiles. IFAI Expo 2002; 24-26 October 2002; Charlotte, NC, USA. http://www.texere.no/Medicaltex/ClinicalStudies.aspx. Antimicrobial Performance of Medical Textiles.

[14] Malek JR, Speier JL. Development of an Organosilicone Antimicrobial Agent for the Treatment of Surfaces. Journal of Coated Fabrics 1982; 12: 38-46.

[15] Curtis A, Biocidal Antimicrobial Barrier, Medicaltex, http://tmconline.org/userfiles/file/AKG_Sunumlar/21nisan/andrew_curtis\%20_biocidal_anti_microbial_barrier \%20. pdf, 2012.

[16] Lippincott ER, Van Valkenburg A, Weir CE, Bunting EN. Infrared Studies on Polymorphs of Silicon Dioxide and Germanium Dioxide. Journal of Research of the National Bureau of Standards 1958; 61(1): 61-70.

[17] Bobrowski A, Stypula B, Hutera B, Kmita A, Drozynski D, Starowicz M. FTIR spectroscopy of water glass - the binder moulding modified by ZnO nanoparticles. Metalurgija 2012; 51(4): 477-480.

[18] Beganskiene A, Sirutkaitis V, Kurtinaitiene M, Juskenas R, Karieva A. FTIR, TEM and NMR Investigations of Stober Silica Particles. Materilas Science 2004; 10(4): 287-290.

[19] Serra J, González P, Liste S, Serra C, Chiussi S, León B, Pérez-Amor M, Ylänen HO, Hupa M. FTIR and XPS Studies of Bioactive Silica Based Glasses. Journal of Noncrystalline Solids 2000; 232(13): $20-27$.

[20] Brinker CJ, Scherer GW. Sol-Gel Science. The Physics and Chemistry of Sol-Gel Processing. New York, Academic Press Inc,1990. 